\title{
Pengaruh Kompetensi Pedagogik Guru dan Gaya Belajar Siswa Terhadap Prestasi Belajar Siswa Pada Mata Pelajaran IPS
}

\author{
Tribagus Kuncoro Sakti ${ }^{1}$, Nanis Hairunisya ${ }^{2}$, Imam Sukwatus Sujai ${ }^{3}$ \\ 1 tribaguskuncoro@gmail.com \\ 1, 2, 3 STKIP PGRI Tulungagung
}

$\begin{array}{ccc}\text { Submitted } & \text { Revised } & \text { Accepted } \\ \text { September 3, 2018 } & \text { June 24, 2019 } & \text { June 25, 2019 } \\ & \text { http://dx.doi.org/10.17509/jpis.v28i1.12818 } & \end{array}$

\begin{abstract}
This study aims to determine the effect of teacher's pedagogic competence on student achievement on social studies, to determine the effect of student learning styles on student learning achievement in social studies, find out how much influence the teacher's pedagogic competence. This research is quantitative research. Data collection method is a questionnaire method. Data analysis uses percentages and multiple linear regression. there is a significant influence of the variables of teacher's paedagogic competence $\left(X_{1}\right)$ and student learning style $\left(X_{2}\right)$ on student achievement variables (Y) in social studies at SDN 1 Aryojeding school year 2017/2018, this is based on Fcount value 39.706 2.87 in ftabel with a significance level of $0.000<0.05$ which means significant.
\end{abstract}

Keywords: Pedagogic Competence, Learning Style

\begin{abstract}
ABSTRAK
Penelitian ini bertujuan untuk mengetahui pengaruh kompetensi pedagogik guru terhadap prestasi belajar siswa pada mata pelajaran IPS, mengetahui pengaruh gaya belajar siswa terhadap prestasi belajar siswa pada mata pelajaran IPS, mengetahui seberapa besar pengaruh kompetensi pedagogik guru, gaya belajar siswa/ Penelitian ini merupakan penelitian kuantitatif. Metode pengumpulan data adalah metode kuesioner (kuesioner). Analisis data menggunakan persentase dan regresi linier berganda. ada pengaruh signifikan dari variabel kompetensi paedagogik guru (X1) dan gaya belajar siswa (X2) pada variabel prestasi belajar ( $Y$ ) siswa dalam studi sosial di SDN 1 Aryojeding tahun ajaran sekolah 2017/2018, ini didasarkan pada nilai Fcount 39.706> 2.87 dalam ftabel dengan tingkat signifikansi 0,000 <0,05 yang berarti signifikan.
\end{abstract}

Kata Kunci: Kompetensi Pedagogik, Gaya Belajar

\section{PENDAHULUAN}

Kemampuan guru dalam proses pembelajaran sangat mempengaruhi perkembangan pendidikan. Hal ini karena tidak semua guru dapat mengajar muridnya dengan baik atau profesional. Pada kenyataannya dalam melaksanakan pengajaran, banyak pendidik yang masih mengalami kesulitan untuk memberikan pengajaran kepada murid sehingga murid sulit untuk memahami materi. Guru merupakan salah satu profesi yang berperan dalam membentuk dan menentukan kualitas SDM di masa yang aka datang [1]. Oleh sebab itu, untuk mendapatkan SDM berkualitas di masa yang akan datang, 
maka diperlukan guru yang berkualitas pula. Salah satu cara untuk meningkatkan kualitas guru adalah dengan meningkatkan kompetensinya.

Sebagaimana yang tertuang dalam UU No. 14 tahun 2005 tentang guru dan dosen, salah satu upaya yang dilakukan agar guru menjadi profesional agar dapat memajukan dan menjadikan pendidikan yang berkualitas adalah dengan memiliki kompetensi pedagogik. Kompetensi pedagogik yaitu kemampuan seorang guru dalam mengelola proses pembelajaran siswa.

Kompetensi pedagogik adalah salah satu kompetensi yang difokuskan oleh peneliti karena mempengaruhi prestasi belajar siswa [2]. Kompetensi pedagogik guru merupakan kemampuan kognitif guru dalam melaksanakan proses-proses pembelajaran dan pengelolaan peserta didik yang sekurang-kurangnya meliputi keterampilan dasar mengajar dan penggunaan teknologi pembelajaran [3].

Selain kompetensi pedogagik guru, gaya belajar siswa juga menentukan prestasi belajar siswa. Gaya belajar adalah salah satu aspek yang perlu mendapat perhatian. Gaya belajar merupakan cara termudah yang harus dimiliki individu untuk dapat menyerap, mengatur dan mengelola informasi yang diterima. Gaya belajar siswa merupakan cara siswa bereaksi dan menggunakan perangsangperangsang yang diterimanya dalam proses belajar [4]. Gaya belajar yang sesuai adalah kunci keberhasilan seseorang dalam belajar. Dalam kegiatan belajar siswa memerlukan bantuan dan pengarahan untuk mengenali gaya belajar yang sesuai dengan dirinya, sehingga tujuan pembelajaran dapat dicapai secara optimal. Gaya belajar merupkan salah satu faktor individual atau faktor internal yang mempengaruhi prestasi belajar siswa dan dapat dijadikan modal siswa untuk mencapai prestasi belajar dengan baik. Hal tersebut tentunya tidak terlepas dari peran serta berbagai elemen pendidikan yang ada, di mana sekolah merupakan salah satu elemen penting pencapaian prestasi belajar siswa secara optimal.

Latar belakang lingkungan keluarga siswa juga ikut mempengaruhi prestasi belajar. Keluarga adalah lembaga pendidikan informal (luar sekolah) yang diakui keberadaannya dalam dunia pendidikan [5]. Keluarga merupakan lingkungan pertama dan utama yang dikenal oleh anak. Pemberian pengalaman pendidikan awal mulanya dari keluarga. Pendidikan dikeluarga yang utamanya dilakukan oleh orang tua merupakan pendidikan yang serius dan berkelanjutan untuk menentukan masa depan anak tersebut. Pendidikan dalam keluarga pada dasarnya merupakan komunikasi timbal balik antara orang tua dengan anak melalui pembinaan bahasa, tandatanda tertentu, simbol-simbol yang bermuatan nilai yang tergambar dalam perilaku sosial sehari-hari. Pendidikan keluarga juga merupakan dasar dari pendidikan anak sehingga untuk memperoleh pengetahuan dan pengalaman yang lain maka keluarga dengan kesadaran memberikan pendidikan diluar keluarga yaitu dengan menyekolahkan anaknya.

SDN I Ariyojeding kecamatan Rejotangan kabupaten Tulungagung terletak di wilayah pinggiran dengan jarak yang jauh dari ibukota kabupaten. Dengan jarak yang jauh dari ibukota kabupaten, maka peningkatan kualitas guru di sekolah perlu ditingkatkan. Dalam kegiatan belajar pembelajaran, guru hanya menggunakan metode 
mengajar yang monoton, yaitu ceramah. Penggunaan media dan bahan pengajaran juga jarang dilakukan. Pengelolaan kelas juga belum dilaksanakan secara optimal.

Prestasi belajar merupakan hal yang dipandang dari dua sisi yaitu dari sisi siswa dan dari sisi guru [6]. Dari sisi siswa prestasi belajar merupakan tingkat perkembangan mental yang lebih baik bila dibandingkan pada saat sebelum belajar. Tingkat perkembangan mental tersebut terwujud pada jenisjenis ranah kognitif, afektif dan psikomotorik. Sedangkan dari sisi guru, hasil belajar merupakan saat terselesaikannya bahan pelajaran.

Ditinjau dari latar belakang diatas peneliti bermaksud untuk mengkaji lebih lanjut Tentang Pengruh Pengaruh Kompetensi Pedagogik Guru dan Gaya Belajar Siswa Terhadap Prestasi Belajar Siswa Pada Mata Pelajaran Ips Di Sdn I Ariyojeding Tahun Pelajaran 2017/2018.

\section{METODE PENELITIAN}

Penelitian ini tergolong dalam penelitian eksplanasi yaitu penelitian yang sifatnya untuk mengetahui adanya hubungan sebab akibat di antara dua variabel atau lebih [7]. Variabel yang mempengaruhi prestasi belajar IPS siswa Sekolah Dasar Negeri I Ariyojeding adalah kompetensi pedagogik guru dan gaya belajar.

Dalam penelitian ini, penulis ingin meneliti pengaruh kompetensi pedagogik guru (X1) dan gaya belajar (X2) terhadap prestasi belajar (Y) IPS siswa Sekolah Dasar Negeri I Ariyojeding Kecamatan Rejotangan Tulungagung.

1. Pendekatan Penelitian

Model penelitian yang digunakan dalam penelitian ini adalah model penelitian kuantitatif

2. Lokasi dan Waktu Penelitian
Penelitian ini dilaksanakan di SDN 1 Ariyojeding semester genap tahun ajaran 2017/2018. Kegiatan penelitian ini dilaksanakan pada tanggal 19 - 30 Maret 2018.

3. Populasi penelitian

Populasi adalah keseluruhan subjek penelitian [7]. Apabila seseorang ingin meneliti semua elemen yang ada dalam wilayah penelitian, maka penelitiannya merupakan penelitian populasi. Populasi adalah wilayah generalisasi yang terdiri atas, objek/subjek yang mempunyai kualitas dan karakteristik tertentu yang ditetapkan oleh peneliti untuk dipelajari dan kemudian ditarik kesimpulannya [8].

Berdasarkan uraian di atas, maka populasi dalam penelitian ini adalah siswa Sekolah Dasar Negeri I Ariyojeding Kecamatan Rejotangan Tulungagung.

\section{Sampel Penelitian}

Sampel adalah sebagian atau wakil populasi yang diteliti [9]. Sampel adalah bagian dari jumlah dan karakteristik yang dimilki oleh populasi tersebut [8].

Pedoman penentuan jumlah sampel adalah apabila jumlah populasi kurang dari 100, lebih baik diambil semua. Selanjutnya, jika jumlah sampel besar dapat diambil antara $10 \%-15 \%$ atau $20 \%-25 \%$ atau lebih tergantung dari kemampuan peneliti dilihat dari waktu, tenaga dan dana [9].

5. Teknik Analisis Data

Yang dimaksud dengan instrument penelitian di sini adalah pengukuran variabel-variabel yang diteliti. Uji coba instrumen dilaksanakan terhadap 40 responden dengan analisis hasil uji coba yang dilakukan dengan uji validitas dan reliabelitas 
yang analisanya menggunakan komputer program SPSS 21.

a. Uji Asumsi

Salah satu syarat dalam menggunakan model regresi linier berganda adalah terpenuhinya uji asumsi klasik yang meliputi :

1. Uji Normalitas Data

Uji normalitas ini dilakukan untuk mengetahui apakah data variabelvariabel yang diteliti berdistribusi normal atau tidak. Uji normalitas dapat dilakukan dengan menggunakan uji Normal P-P Plot atau Plot Probabilitas Normal. Model regresi dikatakan normal apabila titiktitik berkumpul disekitar garis diagonal naik ke atas secara fluktuatif.

2. Uji Heteroskedastisitas.

Metode ini digunakan untuk mengetahui apakah terjadi ketidaksamaan varians dari residual pada satu pengamatan ke pengamatan yang lain. Jika terdapat perbedaan varians maka terdapat gejala heteroskedastisitas. Deteksi ada tidaknya gejala heteroskedastisitas adalah dengan melihat ada tidaknya pola tertentu pada grafik scatterplotdisekitar nilai $\mathrm{X}$ dan $\mathrm{Y}$.

b. Uji Hipotesis

Langkah selanjutnya dalam melakukan analisis data, yaitu melakukan pengujian hipotesis dengan:

1. Uji $(t)$

Digunakan untuk mengetahui pengaruh variabel-variabel bebas (independent) secara individu atau parsial terhadap variabel terikat (dependent).

thitung $=\frac{r \sqrt{n-2}}{\sqrt{1-r^{2}}}$

[7]

Keterangan : $r$ : koefisien korelasi

$\mathrm{n}$ : jumlah sampel

Adapun uji hipotesisnya adalah :

Jika nilai $\mathrm{t}$ hitung $<\mathrm{t}$ tablemaka $\mathrm{HO}$ diterima dan $\mathrm{Ha}$ ditolak. Jika nilai $\mathrm{t}$ hitung> t tabelmaka $\mathrm{HO}$ ditolak dan Ha diterima.

2. Uji $F$

Digunakan untuk menguji pengaruh dari seluruh variabel bebas (independent) secara simultan terhadap variabel terikat (dependent).

$$
F_{\text {hitung }}=\frac{R^{2}(n-m-1)}{m \cdot\left(1-R^{2}\right)}
$$

[9]

Keterangan:

$F$ : nilai $F$ yang dihitung

$\mathrm{R}$ : nilai koefisien determinan

$\mathrm{n}$ : jumlah sampel

$\mathrm{m}$ : jumlah variabel bebas

Adapun uji hipotesisnya adalah:

Jika nilai $\mathrm{F}$ hitung $<\mathrm{F}$ tabelmaka $\mathrm{HO}$ diterima dan $\mathrm{Ha}$ ditolak

Jika nilai $\mathrm{F}$ hitung> $\mathrm{F}$ tabel maka $\mathrm{HO}$ ditolak dan Ha diterima

c. Regresi Linier Berganda

Menurut [7] Analisis regresi berganda adalah analisis tentang hubungan antara satu dependent variable dengan dua atau lebih independent variabel. Analisis ini digunakan untuk mencari kompetensi pedagogik guru (X1) dan gaya belajar (X2) terhadap prestasi belajar $(\mathrm{Y})$ siswa SDN Ariyojeding I Kecamatan Rejotangan Kabupaten Tulungagung tahun pelajaran 2017/2018.

Rumus persamaan regresi linier berganda sebagai berikut:

\begin{tabular}{l}
\hline $\mathrm{Y}=\mathrm{a}+\mathrm{b}_{1} \mathrm{X}_{1}+\mathrm{b}_{2} \mathrm{X}_{2}+\mathrm{b}_{3} \mathrm{X}_{3}+\mathrm{e}$ \\
\hline$[10]$ \\
Keterangan: \\
$\mathrm{Y}$ : prestasi belajar \\
$\mathrm{a}$ : konstanta
\end{tabular}


b1b2: koefisien regresi dari variabel bebas

$\mathrm{X}$ 1: kompetensi pedagogik guru

$\mathrm{X}_{2}$ : motivasi belajar

$X_{3}$ : sarana prasarana pendidikan

e : eror

Untuk mengetahui besarnya pengaruh bersama variabel $X_{1}$ dan $X_{2}$ terhadap $Y$ dengan menggunakan rumus koefisien determinan sebagai berikut:

\begin{tabular}{l}
$\mathrm{KP}=\mathrm{r}^{2} \times 100 \%$ \\
\hline 10$]$
\end{tabular}

Keterangan :

$\mathrm{Kd}$ : nilai koefisien determinan

$r$ : nilai koefisien korelasi

\section{HASIL DAN PEMBAHASAN}

\section{Uji Validitas dan Reliabilitas}

Pada bagian hasil dan kesimpulan peneliti akan membahas beberapa hal terkait dengan hasil analisis data yang sudah diperoleh. Beberapa hal tersebut yakni interpretasi hasil penelitian, perbandingan hasil penelitian yang dilaksanakan dengan teori, dan perbandingan dengan penelitian yang relevan. Kemudian, beberapa hal tersebut peneliti bahas sebagai berikut: 1. Interpretasi Hasil Penelitian

$$
\text { Berdasarkan analisis data }
$$

dengan perangkat lunak (software) SPSS for Windows version 21 menunjukan bahwa persamaan regresi linier berganda $\mathrm{Y}$ (prestasi belajar) = $64,375+0,122$ X1 (kopetensi paedagogik guru) +0.466 X2 (gaya belajar siswa) yang berarti konstanta 64,375 menunjukkan bahwa jika tidak ada $\mathrm{X}_{1}$ (kompetensi paedagogik guru) dan $\mathrm{X}_{2}$ (gaya belajar siswa). Koefisien regresi 0,122 X1 (kompetensi paedagogik guru) menunjukkan bahwa setiap penambahan 1 tingkat kompetensi paedagogik guru, maka akan meningkatkan prestasi belajar siswa sebesar 0.122 , sebaliknya jika penurunan
1 tingkat kompetensi paedagogik guru, maka akan terjadi penurunan prestasi belajar sebesar 0.122 dengan ketentuan variabel lain adalah tetap atau tidak berubah. Koefisien regresi $\mathrm{X}_{2}$ (gaya belajar siswa) menunjukkan bahwa setiap penambahan satu tingkat gaya belajar siswa, maka akan meningkatkan prestasi belajar sebesar 0.466, sebaliknya jika ada penurunan 1 tingkat gaya belajar siswa, maka akan menurunkan prestasi belajar sebesar 0.466 dengan ketentuan variabel lain adalah tetap atau tidak berubah.

Berdasarkan analisis data dengan perangkat lunak (software) SPSS for Windows version 21 dapat disimpulkan bahwa ada pengaruh yang signifikan antara kompetensi pedagogik guru terhadap prestasi belajar siswa pada mata pelajaran IPS di SDN 1 Aryojeding tahun pelajaran 2017/2018, hal ini berdasarkan thitung sebesar 2,473> 2,030 pada ttabel dengan tingkat signifikansi 0,021 < 0.05 yang berarti signifikan, serta dapat disimpulkan ada pengaruh yang signifikan antara gaya belajar siswa terhadap prestasi belajar siswa pada mata pelajaran IPS di SDN 1 Aryojeding tahun pelajaran 2017/2018 adalah signifikan, hal ini berdasarkan thitung sebesar 2,807>2,030 pada ttabel dengan tingkat signifikansi 0,012 < 0.05 yang berarti signifikan.

Berdasarkan analisis data dengan perangkat lunak (software) SPSS for Windows version 21 dapat disimpulkan bahwa ada pengaruh yang signifikan dari variabel kompetensi paedagogik guru (X1) dan gaya belajar siswa (X2) terhadap variabel prestasi belajar (Y) siswa pada mata pelajaran IPS di SDN 1 Aryojeding tahun pelajaran 2017/2018, hal ini berdasarkan nilai Fhitung 39,706 > 2,87 pada ftabel dengan tingkat signifikansi $0,000<0.05$ yang berarti signifikan. 
2. Perbandingan Hasil Penelitian yang Dilaksanakan dengan Teori

a. Hasil penelitian ini menujukkan ada pengaruh yang signifikan antara kompetensi pedagogik guru terhadap prestasi belajar siswa pada mata pelajaran IPS di SDN 1 Aryojeding tahun pelajaran 2017/2018. Tujuan bimbingan belajar adalah membantu siswa agar mendapatkan penyesuaian yang baik di dalam situasi belajarnya [11]. Bimbingan belajar merupakan salah satu faktor penting dalam mempengaruhi prestasi belajar yang ingin dicapai oleh siswa dikarenakan dengan mengikuti bimbingan belajar diluar sekolah dapat membantu siswa yang mengalami masalah didalam memasuki proses belajar yang dihadapinya. Berdasarkan hasil penelitian ini yang menunjukkan ada pengaruh dari bimbingan belajar diluar sekolah terhadap prestasi belajar, maka peneliti menyatakan bahwa siswa SDN I Aryojding banyak yang mengikuti bimbingan belajar diluar sekolah untuk mendapatkan penyesuaian yang baik di dalam situasi belajar, sehingga setiap siswa dapat belajar dengan efisien sesuai kemampuan yang dimilikinya, mencapai perkembangan yang optimal dan hal tersebut memperkuat pernyataan dari [11].

b. Hasil penelitian ini menunjukkan ada pengaruh yang signifikan antara gaya belajar terhadap prestasi belajar siswa pada mata pelajaran IPS di SDN 1 Aryojeding tahun pelajaran 2017/2018. Ketaatan dan kepatuhan dalam melaksanakan aktivitas belajar sesuai aturannya untuk mencapai tujuan yang diharapkannya, keterikatan antara disiplin belajar dengan hasil belajar sangat erat sehingga semakin berdisiplin dalam belajar semakin baik hasil yang dicapai [12]. Berdasarkan hasil penelitian ini yang menunjukkan ada pengaruh dari disiplin belajar terhadap prestasi belajar siswa, maka peneliti menyatakan bahwa dalam penelitian ini siswa yang mempunyai sikap disiplin belajar akan mampu mengkondisikan dirinya untuk belajar sesuai dengan harapan, sehingga hal ini memungkinkan siswa untuk mencapai hasil belajar yang memuaskan dan mendapatkan prestasi belajar yang baik [9].

c. Ketaatan dan kepatuhan dalam melaksanakan aktivitas belajar sesuai aturannya untuk mencapai tujuan yang diharapkannya, keterikatan antara disiplin belajar dengan hasil belajar sangat erat sehingga semakin berdisiplin dalam belajar semakin baik hasil yang dicapai [12]. Berdasarkan hasil penelitian ini yang menunjukkan ada pengaruh dari disiplin belajar terhadap prestasi belajar siswa, maka peneliti menyatakan bahwa dalam penelitian ini siswa yang mempunyai sikap disiplin belajar akan mampu mengkondisikan dirinya untuk belajar sesuai dengan harapan, sehingga hal ini memungkinkan siswa untuk mencapai hasil belajar yang memuaskan dan mendapatkan prestasi belajar yang baik [12].

\section{SIMPULAN}

Berdasarkan hasil analisis dan pembahasan, maka dapat ditarik kesimpulan Terdapat pengaruh yang signifikan antara kompetensi pedagogik guru terhadap prestasi belajar siswa pada mata pelajaran IPS di SDN 1 Aryojeding tahun pelajaran 2017/2018, hal ini berdasarkan thitung sebesar 2,473 > 2,030 pada ttabel dengan tingkat signifikansi $0,021<0.05$. 
Terdapat pengaruh yang signifikan antara gaya belajar siswa terhadap prestasi belajar siswa pada mata pelajaran IPS di SDN 1 Aryojeding tahun pelajaran 2017/2018 adalah signifikan, hal ini berdasarkan thitung sebesar 2,807 > 2,030 pada ttabel dengan tingkat signifikansi $0,012<0.05$.

pengaruh yang signifikan dari variabel kompetensi paedagogik guru (X1) dan gaya belajar siswa (X2) terhadap variabel prestasi belajar $(\mathrm{Y})$ siswa pada mata pelajaran IPS di SDN 1 Aryojeding tahun pelajaran 2017/2018, hal ini berdasarkan nilai Fhitung 39,706 > 2,87 pada ftabel dengan tingkat signifikansi $0,000<0.05$.

\section{REKOMENDASI}

Berdasarkan hasil penelitian dan kesimpulan yang telah diuraikan di atas Bagi Guru disarankan meningkatkan kompetensi professional dengan cara menguasai standar kompetensi dan kompetensi dasar mata pelajaran yang diampu dan mengembangkan materi pelajaran yang diampu secara kreatif, dan menggunakan model dan metode pembelajaran yang lebih bervariasi.

Bagi sekolah disarankan untuk menambah dan melengkapi segala fasilitas belajar yang diperlukan para siswa, seperti: buku pelajaran IPS, buku bacaan, alat dan fasilitas pembelajaran seperti: LCD, komputer, internet, sehingga dapat memudahkan dan melancarkan pelaksanaan pembelajaran dan prestasi belajar siswa dapat dicapai dengan maksimal.

Bagi Siswa disarankan untuk meningkatkan prestasi belajar dengan cara menumbuhkan motivasi belajar dalam diri siswa, dengan cara: Membiasakan diri untuk mempelajari hal-hal yang berkaitan dengan ilmu pengetahuan sosial, agar tercipta rasa suka dan rasa keterikatan pada mata pelajaran IPS, sehingga siswa memiliki kesadaran untuk mempelajari dan memahami materi IPS yang akan dan telah disampaikan oleh guru dan pada akhirnya prestasi belajar IPS dapat dicapai dengan maksimal.

Berdasarkan hasil penelitian ditemukan koefisien diterminasi sebesar 0,797 . Hal ini berarti 79,7 \% perubahan variabel $Y$ dipengaruhi oleh variabel $X$ maka disarankan bagi peneliti selanjutnya untuk prestasi belajar menggunakan variabel lain.

\section{DAFTAR PUSTAKA}

[1] H. Murwati, "Pengaruh sertifikasi profesi guru terhadap motivasi kerja dan kinerja guru di smk negeri se-Surakarta," Pendidik. Bisnis dan Ekon., vol. 1, no. 1, pp. 110, 2013.

[2] R. Umami, "Pengaruh Kompetensi Pedagogik dan Motivasi Kerja Guru terhadap Prestasi Belajar Siswa dalam Ujian Nasional (UN) di SMA Negeri se Kota Mojokerto," Inspirasi Manaj. Pendidik., vol. 3, no. 3, 2014.

[3] M. Irham and N. A. Wiyani, Psikologi Pendidikan: Teori dan Aplikasi dalam proses pembelajaran. Yogyakarta: ArRuzz Media, 2013.

[4] S. Nasution, Berbagai Pendekatan dalam Proses Belejar Mengajar. Jakarta: Bumi Aksara, 2000.

[5] S. B. Djamarah, Psikologi Belajar. Jakarta: Rineka Cipta, 2011.

[6] Dimyati and Mujiono, Belajar dan Pembelajaran. Jakarta: Rineka Cipta, 2013.

[7] S. Arikunto, Prosedur Penelitian Suatu Pendekatan Praktik. 
Jakarta: Rineka Cipta, 2010.

[8] Sugiyono, Metode Penelitian Pendidikan: Pendekatan Kuantitatif, Kualitatif, dan R\&D. Bandung: Alfabeta, 2015.

[9] S. Arikunto, Prosedur Penelitian Suatu Pendekatan Praktik. Jakarta: Rineka Cipta, 2013.
[10] Riduwan, Dasar-dasar Statistika. Jakarta: Alfabeta, 2013.

[11] S. Abu, Ahmadi. Widodo, Psikologi Belajar. Jakarta: Rineka Cipta, 2008.

[12] B. Walgito, Pengantar Psikologi Umum. Jakarta, 2004. 